\title{
Predictors of in-hospital mortality in patients with non-variceal upper gastrointestinal bleeding
}

\author{
José Alberto González-González, Genaro Vázquez-Elizondo, Diego García-Compeán, \\ Juan Obed Gaytán-Torres, Ángel Ricardo Flores-Rendón, Joel Omar Jáquez-Quintana, \\ Aldo Azael Garza-Galindo, Martha Graciela Cárdenas-Sandoval and Héctor Jesús Maldonado-Garza
}

Department of Gastroenterology. Hospital Universitario de Monterrey “Dr. José Eleuterio González” y Escuela de Medicina. Universidad Autónoma de Nuevo León. Monterrey, Nuevo León. Mexico

\begin{abstract}
Objective: to determine the independent predictors of in-hospital death of Hispanic patients with nonvariceal upper gastrointestinal bleeding (NVUGB).

Experimental design: prospective and observational trial.

Patients: in a period between 2000 and 2009, all patients with NVUGB admitted to our hospital were studied. Demographical and clinical characteristics, endoscopic findings and laboratory tests were evaluated. $\chi^{2}$ and Mann-Whitney $U$ analyses were performed for comparisons, and binary logistic regression was employed to identify independent predictors of in-hospital mortality.

Results: 1,067 patients were included, 65\% male with a mean age of 58.8 years. Mean number of comorbidities per patient was $1.6 \pm 0.76$. The most frequent cause of bleeding were gastric and duodenal ulcers (55.4\%); 278 patients (25.8\%) received endoscopic treatment of which $69.1 \%$ had combined therapy. Rebleeding occurred in 36 patients (3.4\%) of which 50\% died. Inhospital mortality was $10.2 \%$, of which only $3.1 \%$ was associated to bleeding. When comparing causes of death among patients with and without comorbidities, only hypovolemic shock was found significative (48.3 vs. 25\%; $p=0.020$ ). Binary logistic regression found that the number of comorbidities, Rockall scale serum albumin $<2.6 \mathrm{~g} / \mathrm{dL}$ on admission; rebleeding and length of hospital stay were independent risk factors of in-hospital mortality.

Conclusion: the number of comorbidities, the Rockall scale score, an albumin level $<2.6 \mathrm{~g} / \mathrm{dL}$, the presence of rebleeding and hospital stay were predictors of in-hospital mortality in patients with UNVGB.
\end{abstract}

Key words: Nonvariceal upper gastrointestinal bleeding. Mortality. Predictive factors. Hispanics.

Received: $13-10-10$.

Accepted: 23-12-10.

Correspondence: José Alberto González. Department of Gastroenterology. Hospital Universitario de Monterrey "Dr. José Eleuterio González". Universidad Autónoma de Nuevo León. Monterrey. Nuevo León Madero y Gonzalitos, s/n. Col. Mitras Centro. Monterrey, N.L. México.

e-mail: joseagonz@yahoo.com
González-González José Alberto, Vázquez-Elizondo Genaro, García-Compeán Diego, Obed Gaytán-Torres Juan, Flores-Rendón Ángel Ricardo, Jáquez-Quintana Joel Omar, Garza-Galindo Aldo Azael, Cárdenas-Sandoval Martha Graciela, Maldonado-Garza Héctor Jesús. Predictors of in-hospital mortality in patients with non-variceal upper gastrointestinal bleeding. Rev Esp Enferm Dig 2011; 103: 196-203.

\section{INTRODUCTION}

Non-variceal upper gastrointestinal bleeding (NVUGB) is a critical condition in which a mortality of 5 to $10 \%$ has been reported in different series of patients. This variability may be explained in part by the different clinical and demographic characteristics of the studied population $(1,2)$. Recent prospective studies have identified different predictors of mortality; it is worth noting that the use of proton pump inhibitors (PPIs) significantly reduces mortality in patients both with and without high risk stigmata of rebleeding. Moreover, the use of endoscopic treatment has been demonstrated to reduce mortality in greater proportion than drug treatment (3-6). However, it has been shown that the risk factors, complications and mortality rates described in controlled trials are lower than those reported in patients who received their attention on "day-today conditions" in a tertiary care community hospital (7), which illustrates more accurately the actual conditions of medical care.

The main objective of our study is to describe the clinical characteristics, endoscopic findings, and treatment used, as well as risk factors of complications and in-hospital mortality in Hispanic patients with NVUGB on "day-to-day conditions". 


\section{METHODS}

Our Hospital is a public tertiary care institution located in northeastern Mexico that serves a population of approximately 3.5 million people. All adult patients (greater than 18 years of age) admitted with NVUGB and those who had in-hospital bleeding from January 2000 to February 2009 were prospectively included in a database previously designed. Age, gender, clinical manifestations of bleeding, history of prior gastrointestinal bleeding, use of tobacco and non-steroidal anti-inflammatory drugs (NSAIDs), and intake of alcohol were included in this database. Diabetes mellitus, cardiovascular disease (defined by the presence of hypertension, stroke or myocardial ischemia), chronic liver disease, chronic obstructive pulmonary disease and cancer were considered as severe comorbidities $(3,8)$. In addition, hemodynamic instability, laboratory results on admission (serum hemoglobin, blood urea nitrogen, and blood albumin), number of units of blood transfused, the prescription of acid secretion blocking drugs (proton pump inhibitors or H2-receptor antagonists) were recorded. The time of performance of the upper endoscopy was determined and patients were stratified according to the Rockall classification (9). Endoscopic lesions responsible of the bleeding were identified and endoscopic treatment was performed according to the findings. Ulcers were classified according to Forrest classification (10). The endoscopic hemostatic technique used, the presence of rebleeding, the need of surgery, and hospital stay were described also. Patients were followed through daily visits during hospitalization or until discharge or death. Hemodynamically unstable patients received intravenous crystalloid solutions and blood according to individual requirements. Decision concerning the type of acid secretion blocking agents used in each patient was taken by the treating physician according to the following protocol: ranitidine $50 \mathrm{mg}$ i.v. every 8 hours and/or omeprazole $40 \mathrm{mg}$ i.v. bolus every 12 hours or by continuous infusion at a rate of $8 \mathrm{mg} / \mathrm{hr}$ for three days and then orally every 12 hours. All endoscopic procedures were performed in the endoscopy unit by professors or by residents on the Gastroenterology Service under supervision of professors. Patients with portal hypertension-related bleeding and those who did not complete their follow-up at our hospital were excluded.

The following terms were defined in advance:

- In-hospital mortality: deaths occurring in hospital after diagnosis and treatment of bleeding. The cause of death and the time of hospital stay (days) were recorded.

- Bleeding episode-related mortality: deaths due to irreversible hypovolemic shock.

- Continued or persistent bleeding: a) failure to achieve hemostasis during endoscopy; b) the presence of blood spontaneously or with aspiration trough a nasogastric tube; c) hypovolemic shock manifested by a heart rate $>100$ beats/minute or hy- potension (systolic blood pressure $<90 \mathrm{mmHg}$ and/or diastolic blood pressure $<60 \mathrm{mmHg}$ ); and d) the need of substantial use of intravenous fluids or transfusion of more than 3 units of blood during 6 hours.

- Rebleeding: the presence of hematemesis, melena or both associated with hypovolemic shock or a decrease in blood hemoglobin $>2 \mathrm{~g} / \mathrm{dL}$ after successful endoscopic treatment and hemodynamic stability for at least 24 hours. All rebleeding episodes were confirmed by upper endoscopy.

- Unidentified cause of bleeding: the observation of blood in the stomach without evidence of a causal injury.

- Hypoalbuminemia: blood albumin level below 3.5 $\mathrm{g} / \mathrm{dL}$.

\section{Ethical aspects}

Despite being a non-interventional study, authorization was requested from each patient to retrieve relevant information on chart and it was verified that all patients included in the study had signed informed consent to diagnostic and therapeutic maneuvers required in each case. The study was approved by the Hospital Ethics Committee.

\section{Statistical analysis}

Categorical variables were expressed as proportions and interquartile ranges (95\% confidence intervals). Continuous variables were expressed as means and standard deviations. Analysis of variance was performed to compare continuous variables using ROC curves in order to determine the best discriminating cut-off value between deceased and surviving patients. Categorical and continuous variables were analyzed using $\chi^{2}$ and Mann-Whitney $\mathrm{U}$ tests to determine the predictors of mortality. Subsequently, the variables that were significant in univariate analysis were analyzed using binary logistic regression to identify independent predictors for death. A $p$ value of less than 0.05 was considered statistically significant. The results were expressed as odds ratios (OR) and 95\% confidence intervals $(95 \% \mathrm{CI})$. All statistical analyses were done using the statistical package SPSS v17.0 (Chicago, Illinois, USA).

\section{RESULTS}

\section{Patients}

During the study period, 2,217 patients with upper gastrointestinal bleeding were admitted. In 1,140 patients, the bleeding was caused by rupture of esophageal varices, and 
1,077 patients were diagnosed with NVUGB. On the other hand, 10 patients were excluded because they were referred to other centers. The demographic, clinical, and endoscopic characteristics of 1,067 patients with NVUGB are shown in table I. The mean age was $58.8 \pm 18.9$ years, with a predominance of male patients $(65 \%)$. Moreover, $59.8 \%$ of patients had one or more severe comorbidities, with a mean of $1.6 \pm 0.76$ comorbidities per patient, the most frequent was the presence of cardiovascular disease (31\%) followed by diabetes mellitus $(24.3 \%)$. Regarding risk factors associated with peptic ulcer disease, $42 \%$ of the patients had a history of alcohol chronic ingestion and about one-third a history of chronic use of NSAIDs and tobacco. About $10 \%$ of patients had previous history of GI bleeding and $11.1 \%$ had in-hospital GI bleeding. With regard to laboratory studies, the mean blood hemoglobin on admission was $9.2 \pm 3.4 \mathrm{~g} / \mathrm{dL}$, and it was $\leq 7 \mathrm{~g} / \mathrm{dL}$ in 305 (28\%) of patients. Additionally, $62.1 \%$ of patients required blood transfusion using a mean of 3 packed red blood cells. The mean blood albumin level was $2.7 \pm 0.84$ $\mathrm{g} / \mathrm{dL}$ on admission, and $76.8 \%$ of patients had hypoalbuminemia. Due to the high frequency of this finding, the blood albumin level on admission was studied as a risk factor of mortality, therefore it was determined the best discriminating cut-off value using ROC curve (receiver operating characteristic curve). The value that best predicted mortality was $\leq 2.6 \mathrm{~g} / \mathrm{dL}$ (Fig. 1); $42 \%$ of patients had a lesser value.

In $62.8 \%$ of patients, the upper endoscopy was performed during the first 24 hours after admission. Gastric or duodenal ulcers were the cause of the bleeding episode in $55.4 \%$ of patients, while the cause of bleeding was not found in $4.3 \%$ of cases. Mean value of the Rockall scoring system was $4.6 \pm 2.1$ at admission, and $51.5 \%$ of patients had a value $\geq 5$.

\section{Pharmacological and endoscopic treatment}

In total, $46.9 \%$ of patients received endoscopic treatment (Table II). Combined therapy (adrenaline injection plus thermal) was used in $69.1 \%$ of patients, whereas epinephrine injection alone was used in $16.5 \%$ of cases. All patients received anti-secretory therapy; PPIs were the most frequently used drug (54.4\%). No statistically significant differences were found by assessing the mortality according to the type of anti-secretory therapy used.

\section{Clinical results}

Rebleeding occurred in 36 patients (3.4\%), of which half died. In total, 16 patients were treated surgically (1.5\%). Overall mortality was $10.2 \%$ (109/1069) (Table II). The mean age of the patients who died was higher than those who survived $(62 \pm 17.7 v s .58 .4 \pm 19$ years $)$. Although there was a statistically significant difference in univariate analysis, age was not a predictor of mortality in the logistic regression analysis (Table III). The mean length of hospital stay was 6.7 days (range 1-118 days) in all patients. Nevertheless, the mean length of hospital stay of patients who survived was significantly shorter than the one who died $(6.1 \pm 7.8 v s .12 \pm 11.6$ days, $p=$ 0.001 , respectively).

\section{Univariate and logistic regression analyses}

The variables in which statistically significant differences were found in univariate analysis and those that showed significant differences after performing logistic regression analysis are shown in table III.

\section{DISCUSSION}

The results of our study show differences and similarities compared to other studies of similar methodological design. Our patients were younger $(58.8 \pm 18.9$ years $)$ than those of the Italian PNED study (68 \pm 16 years), the Canadian RUGBE study ( $66 \pm 17$ years), as well as the Spanish comparative study $(62.28 \pm 15.18)(11)$. This finding may be explained by the age distribution of our population. Most of our population is located between the second and fourth decade of life (12).

In our series, $60 \%$ of patients had severe comorbidities, predominantly cardiovascular disease and diabetes mellitus. This may be explained by the high rates of obesity and metabolic syndrome that affect our population (13-15). The number of comorbidities was significantly higher in patients who died and it was an independent predictor of death (OR: $1.6 ; 95 \%$ CI: $1-2.5, p=$ $0.045)$. This finding is similar to that observed in other studies, particularly RUGBE and PNED studies $(3,5,8)$. On the other hand, hypovolemic shock as cause of death was significantly higher in patients without comorbidities than in those with comorbidities (48vs. $21 \%$, p = $0.02)$. Similar findings have been recently reported in a cohort of 10,428 patients with peptic ulcer bleeding. Mortality of patients was $6.2 \%$, nevertheless most of the patients died due to multiorgan failure secondary to comorbidities, and only $18.3 \%$ of deaths were due to ulcer-bleeding related causes, most of them without comorbidities (16).

In our study the occurrence of clinical manifestations of bleeding, the frequency of non-ulcerative lesions, the severity of gastrointestinal bleeding and the frequency of endoscopic high-risk stigmata for rebleeding were similar to those reported in the literature (11,17-19). Nevertheless, the use of PPIs was not found as a protector risk factor of death in contrast to that observed in other studies. This may be explained due to the observational nature of the study and because there was a high proportion of patients who received H2RA. Current evidence sug- 
Table I. Clinical and demographic characteristics of patients with NVUGIB $(n=1,067)$

\begin{tabular}{|c|c|c|c|}
\hline Variable & $n(\%)$ & Mean (median, IQR) & $95 \%$ CI/SD \\
\hline Male gender & $694(65)$ & & $62.2-67.9$ \\
\hline Age (years) & - & $58.8(60,45-74)$ & \pm 18.9 \\
\hline Patients with comorbidities & $638(59.8)$ & & $56.8-62.7$ \\
\hline Number of comorbidities per patient & - & $1.6(1,1-2)$ & \pm 0.76 \\
\hline \multicolumn{4}{|l|}{ Comorbidities } \\
\hline Diabetes mellitus & $259(24.3)$ & & $21.7-26.8$ \\
\hline Cardiovascular disease & $339(31.8)$ & & $29-34.6$ \\
\hline Chronic renal disease & $145(13.6)$ & & $11.5-15.6$ \\
\hline Chronic pulmonary disease & $48(4.5)$ & & $3.3-5.7$ \\
\hline Chronic liver disease & $160(15)$ & & $12.9-17.1$ \\
\hline Neoplasia & $59(5.5)$ & & $4.2-6.9$ \\
\hline \multicolumn{4}{|l|}{ Risk Factors } \\
\hline NSAID chronic use & $333(31.2)$ & & 28.4-34 \\
\hline Smoking & $349(32.7)$ & & $29.9-35.5$ \\
\hline Alcohol chronic ingestion & $448(42)$ & & $39-44.9$ \\
\hline Previous bleeding history & $102(9.6)$ & & 7.8-11.3 \\
\hline \multicolumn{4}{|l|}{ Clinical presentation } \\
\hline In-hospital bleeding & $118(11.1)$ & & $9.2-12.9$ \\
\hline Melena & $743(69.6)$ & & $66.9-72.4$ \\
\hline Fresh bloody emesis & $321(30.1)$ & & $27.3-32.8$ \\
\hline Coffe-ground emesis & $356(33.4)$ & & $30.5-36.2$ \\
\hline Hematochezia & $71(6.7)$ & & $5.2-8.2$ \\
\hline Hemodynamic instability & $287(28.6)$ & & $24.2-29.6$ \\
\hline Serum hemoglobin on admission (g/dL) & - & $9.2(9.1,6.6-11.7)$ & \pm 3.4 \\
\hline Serum hemoglobin on admission $\leq 7$ (g/dL) & $305(28.6)$ & & $25.9-31.3$ \\
\hline BUN on admission (mg/dL) & - & $39.3(27.6,16-47.4)$ & \pm 36.2 \\
\hline BUN on admission $\geq 20$ (mg/dL) & $699(65.5)$ & & $62.7-68.4$ \\
\hline Serum albumin level on admission (g/dL) & - & $2.7(2.8,2.2-3.4)$ & \pm 0.84 \\
\hline Patients requiring blood transfusions & $663(62.1)$ & & $59.2-65.1$ \\
\hline Transfusions (units) & - & $3(3,2-4)$ & \pm 1.9 \\
\hline \multicolumn{4}{|l|}{ Endoscopy timing } \\
\hline Less than 24 hours & $670(62.8)$ & & $59.9-65.7$ \\
\hline More than 24 hours & $397(37.2)$ & & $34.3-40.1$ \\
\hline \multicolumn{4}{|l|}{ Cause of bleeding on endoscopy } \\
\hline Gastric ulcers & $308(28.9)$ & & $26.1-31.6$ \\
\hline Duodenal ulcers & $240(22.5)$ & & $20-25$ \\
\hline Gastric and duodenal ulcers & $43(4)$ & & $2.8-5.2$ \\
\hline Esophageal ulcers & $26(2.4)$ & & $1.5-3.4$ \\
\hline Gastroduodenal erosions & $143(13.4)$ & & $11.4-15.4$ \\
\hline Mallory-Weiss tear & $92(8.6)$ & & $7-10.4$ \\
\hline Neoplasia & $71(6.7)$ & & $5.1-8.1$ \\
\hline Angiodysplasia & $27(2.5)$ & & $1.6-3.5$ \\
\hline Cameron lesions & $15(1.4)$ & & $0.7-2.1$ \\
\hline Dieulafoy lesions & $23(2.1)$ & & $1.3-3$ \\
\hline Portal hypertensive gastropathy & $31(2.9)$ & & 1.9-3.9 \\
\hline Duodenal diverticula & $2(0.2)$ & & $0-0.4$ \\
\hline No source of bleeding & $46(4.3)$ & & $3.1-5.5$ \\
\hline Ulcer stigmata of recent hemorrhage & $593(55.5)$ & & \\
\hline White base & $293(49.4)$ & & $45.4-53.4$ \\
\hline Flat spot & $25(4.2)$ & & $2.6-5.8$ \\
\hline Adherent clot & $58(9.8)$ & & 7.4-12.2 \\
\hline Visible vessel & $146(24.6)$ & & $21.1-28.1$ \\
\hline Active bleeding & $72(12.1)$ & & $9.5-14.8$ \\
\hline
\end{tabular}

IQR: interquartile range; SD: standard deviation; Cl: confidence interval; NUVGIB: non-variceal upper gastrointestinal bleeding; NSAIDs; non-steroidal anti-inflammatory; BUN: blood urea nitrogen. 
gests that early administration of PPIs is the standard treatment of patients with NVUGB (20-24).

The rebleeding rate observed in our patients $(3.4 \%)$ was similar to that observed in the Italian PNED study $(3.2 \%)$ and in other recent publications $(17,18)$, but it was significantly lower than that reported in the Canadian RUGBE study $(14.1 \%)(3,5,8)$. The divergence of our results from the ones of the Canadian study may be explained because a higher proportion of our patients received combined endoscopic therapy (adrenaline injection plus BICAP) than in the Canadian study; combined therapy has been shown to be superior to pharmacologic treatment for reduction of rebleeding in controlled trials (25-27). In addition, rebleeding was found to be an independent predictor of death in our study as equal as it has been described in other studies.

Despite progress in the management of patients with NVUGB over recent years, mortality has not been substantially reduced $(28,29)$. This may be explained by the failure to identify mortality-related risk factors different to those already known $(1,9,30)$. The mortality in our patients $(10.2 \%)$ was significantly greater than that reported in PNED and RUGBE studies, but it was lower than that reported in institutions under similar clinical situations $(3,5,7)$. The Rockall scoring system (9) (which combines several clinical, demographic, and endoscopic parameters) has been prospectively validated. In our study Rockall scoring system demonstrated to be an independent predictor of death (OR: 1.3; 95\% CI: 1.01-1.52, $p=$ 0.0001 ). Notwithstanding, Rockall scoring system has limitations due to the clinical and epidemiological differences observed in populations. Thus, despite the demonstrated utility of this scoring system, it is considered that there is currently no ideal method $(8,31)$.

On the other hand, the proportion of our patients with hypoalbuminemia was high $(69.8 \%)$ even in patients

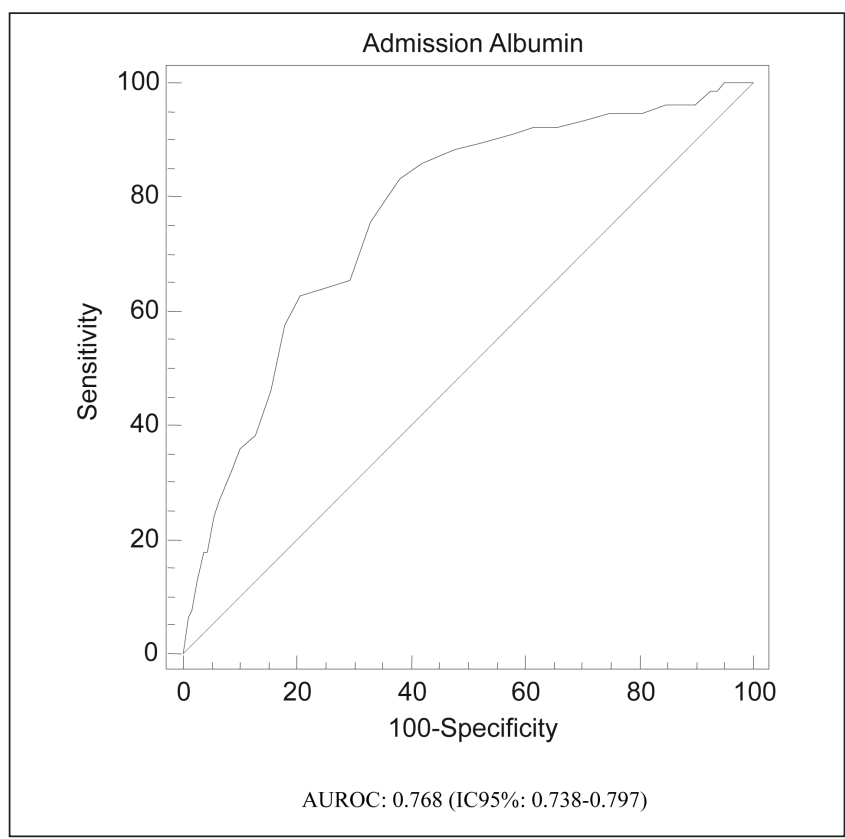

Fig. 1. ROC curve for serum albumin level on admission ( $\mathrm{g} / \mathrm{dL})$. AUROC: 0.768 (IC95\%: 0.738-0.797)

without chronic liver disease. The best mortality-discriminating cut-off value determined by means of ROC curve was $\leq 2.6 \mathrm{~g} / \mathrm{dL}$. Value below this level showed to be an independent predictor of death (OR: $4.9,95 \%$ CI: 2.79.1, $p=0.0001$, ). Hypoalbuminemia is associated with multiple debilitating clinical conditions such as malnutrition, diabetes mellitus, renal failure, and chronic liver disease (32-36). Since albumin has multiple biological functions, it is widely accepted that hypoalbuminemia is a risk factor of mortality in some diseases (35). A recent

Table II. Endoscopic and medical treatment and outcomes of patients with NVUGIB

\begin{tabular}{llll}
\hline Variable & $n$ & $\%$ & CI 95\%/SD \\
\hline Ulcer stigmata of recent hemorrhage & 593 & 55.5 & $49.1-57.1$ \\
Endoscopic treatment & 278 & 46.9 & $42.9-50.9$ \\
Epinephrine injection & 46 & 16.5 & $12.2-20.9$ \\
Thermal coagulation & 38 & 13.6 & $9.6-17.7$ \\
Combined therapy & 192 & 69.1 & $63.6-74.5$ \\
Hemoclips & 9 & 3.6 & $1.2-5.3$ \\
Medical treatment & & 54.4 & $51.4-57.3$ \\
PPI & 580 & 32.3 & $29.5-35.1$ \\
H2R & 345 & 13.3 & $11.3-15.3$ \\
Combined treatment & 142 & & \\
Clinical outcomes & & 3.4 & $2.3-4.4$ \\
Rebleeding & 36 & 1.5 & $0.8-2.2$ \\
Surgical treatment & 16 & 10.2 & $8.4-12$ \\
Deaths & 109 & & \\
\end{tabular}

Cl: confidence interval; SD: standard deviation; PPI's: proton pump inhibitors; H2RA: H2 receptor antagonist. 
Table III. Univariate and multivariate analysis of clinical variables for mortality in patients with NVUGIB

\begin{tabular}{|c|c|c|c|c|c|c|}
\hline \multirow[t]{2}{*}{ Predictor } & \multirow{2}{*}{$\begin{array}{l}\text { Survivors } \\
n=958\end{array}$} & \multirow{2}{*}{$\begin{array}{l}\text { Deaths } \\
n=109\end{array}$} & \multirow{2}{*}{$\begin{array}{l}\text { Analysis } \\
\text { Univariate } \\
p\end{array}$} & \multicolumn{3}{|c|}{ Multivariate analysis } \\
\hline & & & & $\mathrm{C} 195 \%$ & $O R$ & $p$ \\
\hline Age (years) (mean \pm SD) & $58.4 \pm 19$ & $62.4 \pm 17.7$ & 0.019 & - & - & NS \\
\hline In-hospital bleeding, n (\%) & $91(9.5)$ & $27(24.8)$ & 0.0001 & - & - & NS \\
\hline Comorbidities, n (\%) & $558(58.2)$ & $80(73.4)$ & 0.002 & - & - & NS \\
\hline Number of comorbidities per patient (mean \pm SD) & $1.5 \pm 0.7$ & $1.8 \pm 0.9$ & 0.001 & $1-2.5$ & 1.6 & 0.045 \\
\hline Diabetes Mellitus, n (\%) & $221(23.1)$ & $38(34.9)$ & 0.007 & - & - & NS \\
\hline Chronic renal disease, n (\%) & $120(12.5)$ & $25(22.9)$ & 0.003 & - & - & NS \\
\hline BUN on admission $\geq 20 \mathrm{mg} / \mathrm{dL}($ mean $\pm \mathrm{SD})$ & $609(63.6)$ & $90(82.6)$ & 0.0001 & - & - & NS \\
\hline Serum albumin level on admission $\mathrm{g} / \mathrm{dL}$ (Mean \pm SD) & $2.8 \pm 0.82$ & $2.1 \pm 0.69$ & 0.0001 & - & - & NS \\
\hline Serum Albumin level on admission < $2.6 \mathrm{~g} / \mathrm{dL}$ ( $\mathrm{n} \%$ ) & $359(38.2)$ & $74(74.7)$ & 0.0001 & $2.7-9.1$ & 4.9 & 0.0001 \\
\hline Hematochezia, n (\%) & $59(6.2)$ & $12(11)$ & 0.05 & - & - & NS \\
\hline Ulcer with active bleeding, $\mathrm{n}(\%)$ & $59(6.2)$ & $13(11.9)$ & 0.023 & - & - & NS \\
\hline Rebleeding, n (\%) & $18(1.9)$ & $18(16.5)$ & 0.0001 & $2.7-15.4$ & 6.5 & 0.0001 \\
\hline Surgical treatment, n (\%) & $11(1.1)$ & $5(4.6)$ & 0.005 & - & - & NS \\
\hline Transfusions, n (\%) & $584(61)$ & 79 (72.5) & 0.019 & - & - & NS \\
\hline Rockall score pre-endoscopy (mean \pm SD) & $4.4 \pm 2.1$ & $6 \pm 1.7$ & 0.0001 & $1.01-1.52$ & 1.3 & 0.015 \\
\hline Rockall score pre-endoscopy $\geq 5, \mathrm{n}(\%)$ & $462(48.2)$ & $88(80.7)$ & 0.0001 & - & - & NS \\
\hline Length of hospital stay (days) (mean \pm SD) & $6.1 \pm 7.8$ & $12 \pm 11.6$ & 0.0001 & $1.02-1.07$ & 1.04 & 0.0001 \\
\hline
\end{tabular}

BUN: blood urea nitrogen.

study showed that blood albumin $<3 \mathrm{~g} / \mathrm{dL}$ is a predictor of rebleeding in patients admitted to intensive care unit $(37,38)$. However, value of hypoalbuminemia $(\leq 2.6 \mathrm{~g} /$ dL) as predictor of death in these patients remains to be clearly elucidated in future prospective studies.

Finally, our study has certain limitations: the study was conducted for 9 years, so management criteria may have substantially changed during this period. However, it is important to mention that to our knowledge, this is the first prospective study with the biggest number of patients with NVUGB conducted in Hispanic population in which risk factors of in-hospital death were assessed.

In conclusion, our study shows that the number of comorbidities per patient, the score in the Rockall scoring system, blood albumin levels at admission below 2.6 $\mathrm{g} / \mathrm{dL}$, rebleeding, and length of hospital stay were independent predictors of in-hospital mortality in patients with NVUGB.

Table IV. Cause of death in patients with and without comorbidities

\begin{tabular}{|c|c|c|c|c|}
\hline Variable & $\begin{array}{l}\text { Total patients } \\
n=109\end{array}$ & $\begin{array}{l}\text { Patients without } \\
\text { comorbidities } \\
n=29\end{array}$ & $\begin{array}{l}\text { Patients with } \\
\text { comorbidities } \\
n=80\end{array}$ & $p$ \\
\hline Hypovolemic shock, n (\%) & $34(31.2)$ & $14(48.3)$ & $20(25)$ & 0.02 \\
\hline Respiratory failure, n (\%) & $12(11)$ & $3(10.3)$ & $9(11.3)$ & NS \\
\hline Renal failure, $\mathrm{n}(\%)$ & $14(12.8)$ & $2(6.9)$ & $12(85.7)$ & NS \\
\hline Sepsis, n (\%) & $9(8.3)$ & $3(33.3)$ & $6(66.7)$ & NS \\
\hline Neoplasia, n (\%) & $12(11)$ & 0 & $12(15)$ & 0.027 \\
\hline Acute myocardial infarction, n (\%) & $9(8.3)$ & $1(3.4)$ & $8(10)$ & NS \\
\hline Other causes, n (\%) & $19(17.4)$ & $6(20.7)$ & $13(16.3)$ & NS \\
\hline
\end{tabular}

NS: non significant. 


\section{REFERENCES}

1. Laine L. Upper Gastrointestinal bleeding. Clinical update - American Society of Gastrointestinal Endoscopy 2007;14:1-5.

2. Rockall TA, Logan RF, Devlin HB, Northfield TC. Incidence of and mortality from acute upper gastrointestinal haemorrhage in the United Kingdom. Steering Committee and members of the National Audit of Acute Upper Gastrointestinal Haemorrhage. BMJ 1995;311: 222-6.

3. Barkun A, Sabbah S, Enns R, et al. The Canadian Registry on Nonvariceal Upper Gastrointestinal Bleeding and Endoscopy (RUGBE): endoscopic hemostasis and proton pump inhibition are associated with improved outcomes in a real-life setting. Am J Gastroenterol 2004;99:1238-46.

4. Barkun AN, Martel M, Toubouti Y, Rahme E, Bardou M. Endoscopic hemostasis in peptic ulcer bleeding for patients with high-risk lesions: a series of meta-analyses. Gastrointest Endosc 2009;69:786-99.

5. Marmo R, Koch M, Cipolletta L, Capurso L, Pera A, Bianco MA, et al. Predictive factors of mortality from nonvariceal upper gastrointestinal hemorrhage: a multicenter study. Am J Gastroenterol 2008;103: 1639-47; quiz 48 .

6. Muller T, Barkun AN, Martel M. Non-variceal upper GI bleeding in patients already hospitalized for another condition. Am J Gastroenterol 2009; 104:330-9.

7. Fein F, Weber A, Koch S, Festou N, Dupont-Gossard AC, Cervoni JP, et al. The prognosis of patients having received optimal therapy for nonvariceal upper gastrointestinal bleeding might be worse in daily practice than in randomized clinical trials. Eur J Gastroenterol Hepatol 2010;22:361-7.

8. Marmo R, Koch M, Cipolletta L, Capurso L, Grossi E, Cestari R, et al. Predicting mortality in non-variceal upper gastrointestinal bleeders: validation of the Italian PNED score and prospective comparison with the Rockall score. Am J Gastroenterol 2010;105:1284-91.

9. Rockall TA, Logan RF, Devlin HB, Northfield TC. Risk assessment after acute upper gastrointestinal haemorrhage. Gut 1996;38:316-21.

10. Forrest JA, Finlayson ND, Shearman DJ. Endoscopy in gastrointestinal bleeding. Lancet 1974;2:394-7.

11. Jurado Hernandez AM, de Teresa Galvan J, Ruiz-Cabello Jimenez M, Pinel Julian LM. Evolution in the epidemiology of non-variceal upper digestive hemorrhage from 1985 to 2006. Rev Esp Enferm Dig 2008;100:273-7.

12. Población. Número de Habitantes y Pirámide Poblacional. INEGI, 2010. (Accessed December 15, 2010. Available at: http://cuentame. inegi.org.mx/impresion/poblacion/habitantes.asp.)

13. Villalpando S, Shamah-Levy T, Rojas R, Aguilar-Salinas CA. Trends for type 2 diabetes and other cardiovascular risk factors in Mexico from 1993-2006. Salud Publica Mex 2010;52(Supl.1):S72-9.

14. Acosta-Cazares B, Escobedo-de la Pena J. High burden of cardiovascular disease risk factors in Mexico: An epidemic of ischemic heart disease that may be on its way? Am Heart J 2010;160:230-6.

15. Barquera S, Campos-Nonato I, Hernandez-Barrera L, Villalpando S, Rodríguez-Gilabert C, Durazo-Arvizú R, et al. Hypertension in Mexican adults: results from the National Health and Nutrition Survey 2006. Salud Publica Mex 2010;52(Supl.1):S63-71.

16. Sung JJ, Tsoi KK, Ma TK, Yung MY, Lau JY, Chiu PW. Causes of mortality in patients with peptic ulcer bleeding: a prospective cohort study of 10,428 cases. Am J Gastroenterol 2010;105:84-9.

17. Enestvedt BK, Gralnek IM, Mattek N, Lieberman DA, Eisen G. An evaluation of endoscopic indications and findings related to nonvariceal upper-GI hemorrhage in a large multicenter consortium. Gastrointest Endosc 2008;67:422-9.

18. Hearnshaw SA, Logan RF, Lowe D, Travis SP, Murphy MF, Palmer KR. Use of endoscopy for management of acute upper gastrointestinal bleeding in the UK: results of a nationwide audit. Gut 2010; 59:1022-9.
19. Garrido A, Marquez JL, Guerrero FJ, Pizarro MA, Leo E, Giraldez A. Transfusion requirements in patients with gastrointestinal bleeding: a study in a Blood Unit at a referral hospital. Rev Esp Enferm Dig 2006;98:760-9.

20. Baradarian R, Ramdhaney S, Chapalamadugu R, Skoczylas L, Wang $\mathrm{K}$, Rivilis S, et al. Early intensive resuscitation of patients with upper gastrointestinal bleeding decreases mortality. Am J Gastroenterol 2004;99:619-22.

21. Lau JY, Leung WK, Wu JC, Chan FK, Wong VW, Chiu PW, et al Omeprazole before endoscopy in patients with gastrointestinal bleeding. N Engl J Med 2007;356:1631-40.

22. Leontiadis GI, Sharma VK, Howden CW. Proton pump inhibitor therapy for peptic ulcer bleeding: Cochrane collaboration meta-analysis of randomized controlled trials. Mayo Clin Proc 2007;82:286-96.

23. Sung JJ, Barkun A, Kuipers EJ, Mössner J, Jensen DM, Stuart R, et al. Intravenous esomeprazole for prevention of recurrent peptic ulcer bleeding: a randomized trial. Ann Intern Med 2009;150:455-64.

24. Udd M, Miettinen P, Palmu A, Heikkinen M, Janatuinen E, Pasanen $\mathrm{P}$, et al. Regular-dose versus high-dose omeprazole in peptic ulcer bleeding: a prospective randomized double-blind study. Scand J Gastroenterol 2001;36:1332-8.

25. Bianco MA, Rotondano G, Marmo R, Piscopo R, Orsini L, Cipolletta L. Combined epinephrine and bipolar probe coagulation vs. bipolar probe coagulation alone for bleeding peptic ulcer: a randomized, controlled trial. Gastrointest Endosc 2004;60:910-5.

26. Bjorkman DJ, Zaman A, Fennerty MB, Lieberman D, Disario JA, Guest-Warnick G. Urgent vs. elective endoscopy for acute non-variceal upper-GI bleeding: an effectiveness study. Gastrointest Endosc 2004;60:1-8

27. Spiegel BM, Vakil NB, Ofman JJ. Endoscopy for acute nonvariceal upper gastrointestinal tract hemorrhage: is sooner better? A systematic review. Arch Intern Med 2001;161:1393-404.

28. Blatchford O, Murray WR, Blatchford M. A risk score to predict need for treatment for upper-gastrointestinal haemorrhage. Lancet 2000;356:1318-21

29. Ohmann C, Imhof M, Ruppert C, Janzik U, Vogt C, Frieling T, et al Time-trends in the epidemiology of peptic ulcer bleeding. Scand J Gastroenterol 2005;40:914-20.

30. Chiu PW, Ng EK, Cheung FK, Chan FK, Leung WK, Wu JC, et al Predicting mortality in patients with bleeding peptic ulcers after therapeutic endoscopy. Clin Gastroenterol Hepatol 2009;7:311-6; quiz 253.

31. Das A, Wong RC. Prediction of outcome of acute GI hemorrhage: a review of risk scores and predictive models. Gastrointest Endosc 2004;60:85-93.

32. Arroyo V, Fernandez J, Gines P. Pathogenesis and treatment of hepatorenal syndrome. Semin Liver Dis 2008;28:81-95.

33. Franch-Arcas $\mathrm{G}$. The meaning of hypoalbuminaemia in clinical practice. Clin Nutr 2001;20:265-9.

34. Garcia-Compean D, Jaquez-Quintana JO, Gonzalez-Gonzalez JA Maldonado-Garza H. Liver cirrhosis and diabetes: risk factors, pathophysiology, clinical implications and management. World J Gastroenterol 2009;15:280-8.

35. Herrmann FR, Safran C, Levkoff SE, Minaker KL. Serum albumin level on admission as a predictor of death, length of stay, and readmission. Arch Intern Med 1992;152:125-30.

36. Koulaouzidis A, Bhat S, Saeed AA. Spontaneous bacterial peritonitis. World J Gastroenterol 2009;15:1042-9.

37. Cheon JH, Kim JS, Ko SJ, Ye BD, Kim SG, Jung HC, et al. Risk factors for upper gastrointestinal rebleeding in critically ill patients. Hepatogastroenterology 2007;54:766-9.

38. Tung CF, Chow WK, Chang CS, Peng YC, Hu WH. The prevalence and significance of hypoalbuminemia in non-variceal upper gastrointestinal bleeding. Hepatogastroenterology 2007;54:1153-6. 